\title{
EDITORIAL: KOERS VOLUME 81, NO 2, 2016
}

\begin{abstract}
Author:
A.L. Combrink ${ }^{1}$

\section{Affiliation:}

${ }^{1}$ Research associate, Department Languages and Literature, North West University.
\end{abstract}

\section{Correspondence to:}

A Combrink

Email:

editor@koers.co.za

Dates:

31 Oct 2016

\section{How to cite this article:}

Combrink, A., 2016. "Editorial: KOERS Volume 81, No 1, 2016". KOERS - Bulletin for Christian Scholarship, 81(1). Available at: http://dx.doi.org/10.19108/ koers.81.1.2267

\section{Copyright:}

(C) 2016. The Author(s).

Published under the Creative

Commons Attribution License.
Koers $81(2)$ contains a wide range of articles, with quite a few articles coming from other African countries.

The first intriguing article comes from Ghana, with an investigation into the use of social media in the missional field. Given the wide use of cellphones in Africa, it is a timely investigation to determine the extent to which social media can be used in this field - the penetration of these media throughout the world has been revolutionary, and putting these media to the use that the author has done opens up other kinds of possibilities.

Elijah Baloyi investigates the reality and background to sex as an expression of hospitality within a theological context. It raises important issues about patriarchy among other things, and is thought-provoking. He says in the abstract that "... this paper will attempt to unveil how thinking of sexual intercourse as extending a form of hospitality has encouraged the domination and abuse of women in the African context. The study will also unveil how the gift of sex has been misunderstood and misinterpreted in order to subject women to sexual violence and harassment".

Koers has seen a growth in contributions coming from the field of education, with articles ranging from the philosophical to theological to more practical issues. With three articles in this issue dealing with education, one can see a definite trend, and having an African perspective as well as the two South African perspectives makes for interesting reading. The importance of education, especially within a wide philosophical perspective, has been underlined persuasively.

At the other end of the spectrum, Daleen Kruger writes on the Hymn Book of the church - an issue that has seen a fair amount of heated discussion. Her discussion is more technically slanted, and provides good insights - she points out in the abstract of the article that " ... the contrafactumpractice which utilises secular melodies and/or texts as sources in the creation of sacred hymns, is an age-old tradition. This practice generated amongst others a few Protestant hymns (particularly in the German Reformed context), which are viewed today as important hymns in the hymn corpus".

The final contribution of this issue is the article by Danie Strauss, which deals with boundaries and contains an intriguing exploration, within a philosophical context, of the boundaries that people have to experience to feel cherished and safe - " ... the experience and awareness of boundaries form an integral part of being human. This article investigates the systematic philosophical underpinnings of our understanding of the nature of boundaries, in some instances supported by historical considerations. It stands to reason that boundaries are related to our awareness of spatial relationships, even though this awareness cannot avoid incorporating the distinction between entities and properties, reflected in the distinction between the concrete what and the how of reality".

The third issue of 2016 will contain a number of fairly contentious articles, some dealing with the current problems in the country, notably the student unrest and the whole matter of dealing with public symbols such as statues. The Marikana massacre within the context of the complex societal realities of South Africa is also placed under the microscope. It is felt that it would be fitting to fill the final volume of 2016 with articles dealing with such topical and thought-provoking issues. There will also be a review article by Steve Bishop about Kuyperania 2015. 